\title{
Trust of Information Technology Governance in High School Institution (HSI): A Conceptual Framework
}

\author{
Resad Setyadi ${ }^{1,2 *}$, Aedah Abd Rahman ${ }^{2}$, Aang Subiyakto ${ }^{3}$, Anwar Fattah ${ }^{2}$ \\ ${ }^{1}$ Department of Information System, Institut Teknologi Telkom Purwokerto, Indonesia \\ ${ }^{2}$ School of Graduate Studies (ICT), Asia e University, Malaysia \\ ${ }^{3}$ Department of Information System, UIN Syarif Hidayatullah Ciputat, Indonesia \\ * Corresponding Author: \\ Email: resad@ittelkom-pwt.ac.id
}

\begin{abstract}
.
This study aims to build a conceptual framework for previous research. This research is related to High School Institution (HSI) readiness and usability for using the Information Technology Governance Trust (ITGT) model. The findings based on the literature review provide the initial construction and subsequently become a model conceptual framework. The comparison results with previous research indicate an influence between readiness and usability to user trust when implementing Information Technology Governance (ITG.) in an institution. The impact was identified through past literature, namely assessing the relationship between the Readiness domain and the Usability domain towards ITG. By testing HSI users, a trust will appear through testing to develop a framework model research.
\end{abstract}

Keywords: trust, high school institution, information technology governance, readiness, usability.

\section{INTRODUCTION}

Arrangement of information technology in High School Institutions (HSI) is essential, especially during the COVID-19 pandemic; each HSI has different IT management in each school. Information Technology Governance (ITG) and ITG Standardization absence impact each institution's ITG results [1]. If ITG is maximal, it will give marks to users' trust in using IT, be it employees, institutional owners, students, and parents [2]. However, if the institution does not have adequate IT management or does not have ITG, users will not trust the existing IT system.

Information Technology (IT) capability is a necessary factor that must exist in an institution [3]. In this regard, institutions need to provide IT tools and master them to improve their services from information to interaction [4]. The readiness for IT transformation at the Higher Education Institution (HEI) level has become the primary usage trend in operational units [5]. Therefore, HEI requires a third party in IT governance assessment (ITG) to determine the extent to which IT investment budget expenditures have the maximum impact on effectiveness and efficiency in institutional operations [6]. Many studies related to ITG use standard guidelines for information technology management practices, such as COBIT or research on developing a new 
ITG framework model [7], [8]. It has become a general acknowledgment that ITG is a significant factor for HEI in conducting research, administration, and teaching because IT is a strategic tool for HEI [9].

Regarding the need to manage IT, expand organizational strategies and goals into IT, ITG has accepted specific concerns from other researchers [10]. The real function of an ITG is to determine definite expectations of the maximization of IT investment that comes out in proportion to the maximum results from the use of IT by users [11]. ITG also assesses accountability, participation, open communication, supervision, and decision-makers from the institution's management [12]. The following is a gap in research about ITG conducted within HEIs and companies.

Table 1. The Gaps Around in ITG Implementation

\begin{tabular}{|c|c|c|c|c|}
\hline No. Research & Topic & Method & Result & GAP \\
\hline [13] & $\begin{array}{l}\text { Governance } \\
\text { in Firm }\end{array}$ & $\begin{array}{l}\text { interview and } \\
\text { documents } \\
\text { analyses }\end{array}$ & $\begin{array}{l}\text { Firm governance } \\
\text { requires more than } \\
\text { adherence to a set of } \\
\text { principles or a code } \\
\text { of practice }\end{array}$ & $\begin{array}{l}\text { O'Connell research } \\
\text { area: ITG in Firm } \\
\text { This research area: } \\
\text { ITG in High School } \\
\text { institution (HSI) }\end{array}$ \\
\hline$[14]$ & $\begin{array}{l}\text { Analyzing } \\
\text { Information } \\
\text { Technology } \\
\text { Governance } \\
\text { (ITG) in } \\
\text { Higher } \\
\text { Education } \\
\text { Institution } \\
\text { (HEI) }\end{array}$ & $\begin{array}{l}\text { interview and } \\
\text { documents } \\
\text { analyses }\end{array}$ & $\begin{array}{l}\text { Between effective } \\
\text { ITG and the } \\
\text { following } \\
\text { mechanisms in } \\
\text { Organizational } \\
\text { Communication } \\
\text { Systems, there was a } \\
\text { significant positive } \\
\text { relationship }\end{array}$ & $\begin{array}{l}\text { A Fattah research area: } \\
\text { ITG in HEI } \\
\text { This research area: } \\
\text { ITG in HSI }\end{array}$ \\
\hline [15] & $\begin{array}{l}\text { ITG on } \\
\text { Organization }\end{array}$ & $\begin{array}{l}\text { documents } \\
\text { tanalyses }\end{array}$ & $\begin{array}{l}\text { provide direction for } \\
\text { the ITG research } \\
\text { flow and at the same } \\
\text { time seek empirical } \\
\text { data }\end{array}$ & $\begin{array}{l}\text { Haes research Area: } \\
\text { ITG in Organization } \\
\text { This paper area: ITG } \\
\text { in HSI }\end{array}$ \\
\hline$[16]$ & $\begin{array}{l}\text { ITG in Top- } \\
\text { corporate }\end{array}$ & $\begin{array}{l}\text { interview and } \\
\text { documents } \\
\text { analyses }\end{array}$ & $\begin{array}{l}\text { IT and business } \\
\text { process relatedness } \\
\text { lead to IT cost } \\
\text { synergies }\end{array}$ & $\begin{array}{l}\text { Kude research Area: } \\
\text { ITG in Firm } \\
\text { This paper area: } \\
\text { in HSI }\end{array}$ \\
\hline
\end{tabular}

Several studies related to ITG at the HEI level already exist and support a new ITG framework model. However, it is far different from the HSI, in which there is no discussion related to ITG. Even though institutionally it has used IT in all activities, the institution feels that it does not need a third party to analyze IT's effectiveness because it is still considered unimportant. Therefore, this is the right time to initiate initial steps to take the opportunity to do initial research connected to the object of ITG research in the HSI environment, no longer from HEI or companies. It is time to take this 
opportunity to realize ITG research in the HSI environment with locations in Jakarta, Bekasi, and Tangerang. However, attention to ITG research development in the HEI environment and companies is essential compared to analyst specifications and methods.

Few studies state systematically and massively discuss ITG discussions in a connected and continuous manner. Moreover, IT governance research is mainly in business and private organizations, not in public organizations, especially in educational institutions [17]. ITG research in educational institutions already exists; for example, research conducted by Tawafak related to the influence of ITG on academic achievement development as the primary standard of learning at HEI through Learning Management System (LMS) as an e-learning platform [18]. Another researcher with the Control Objectives for Information and Related Technologies (COBIT) investigation format as a high-level ITG and manage framework [19]. Another version of research with the development of the ITG framework model at the HEI level emerged by the way researchers carried out the adoption process in determining the effectiveness of ITG and IT performance in Higher Education (HEI) [6], [20]. Khouja, in his research, stated that there is no agreement on the ITG framework or standards to be used in HEI [9]. However, from the perspective of HEIs, IT governance must be in place to ensure that institutions benefit from investments in IT.

IT's rapid development requires educational institutions to keep up with changing demands so that IT is constantly updated and gives the best service effect to the community. Readiness in accepting and using IT is essential. Besides, it is also critical to concern about the usability of IT when users use it. Through user trust in IT systems, ITG can offer solutions providing guidelines, policies, and procedures to control IT practices and investments.

This study examines users' trust at the HSI level in the use of IT through the readiness of institutions to prepare IT so that it has maximum IT usability. This study tries to open a new perspective with objects at the HSI level towards other researchers and educational institutions if at the HSI level they also need to use and utilize ITG. The purpose of the research is to develop a proposed model for the ITG Trust framework in HSI. Initial model development through literature study; draft research; model development through adoption, integration, and adaptation. Specifically, the adoption that will be used still looks at the relationship between the previous study and arranges it according to the new model that will become a modeling project. This study describes the implementation of ITG in the context of schools in expanding countries.

\section{LITERATURE REVIEW}

In a conceptual mechanism, an ITG has a framework model consisting of three independent variable domains: relational mechanism, process mechanism, and structures mechanism [21].

http://ijstm.inarah.co.id 


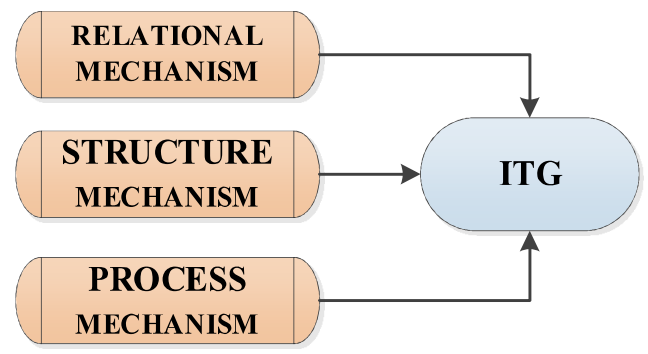

Fig. 1. A Conceptual Mechanism ITG

Figure 1 shows the framework of the conceptual mechanism of De Haes in the organization. The three independent variables in the organization support the high performance of IT utilization. First, the relational mechanism variable describes communication practices and synergies between people with information technology and firm managers, IT management, and business supervision [22], [23]. Second, process mechanism variables describe IT monitoring, direction setting, control, decision making, and evaluation to conform to rules in IT operations [24]. Third, the structure mechanism variable determines the rights and responsibilities of IT business and management decisions related to different activities that involve the use of IT in an organization [25]

The ITG conceptual mechanism has the function of providing a careful explanation of the principles, goals, and values of an ITG improving IT business/alignment [26]. Some authors state the need for companies to have ITG in implementing IT mechanisms [21], [27], [28]. The official ITG Institute (ITGI) explains ITG as a manager, a staff member, and the manner to confirm that organizational IT supports and expands its mission and goals [29]. Changes in mechanisms in several different decentralized ITG locations adjust to political, economic, and social conditions in implementing ITG [30]. The challenges in determining the appropriate tools to suit political, economic, social, and educational requirements in implementing ITG.

Based on the ITG conceptual mechanism study, the authors in developing the ITG model also pay attention to the ITG conceptual mechanism in adopting the previous research model variables [31]. In this study, the ITG conceptual mechanism in developing the ITG model is based on HSI research objects. The domain model variable is derived from the readiness domain variable, the usability domain variable, and the trust variable.

\section{RESEARCH DESIGN}

The ITG Trust framework's drafting stems from the ITG de Haes conceptual mechanism framework model approach. The research procedure of this study is as shown in Figure 2 


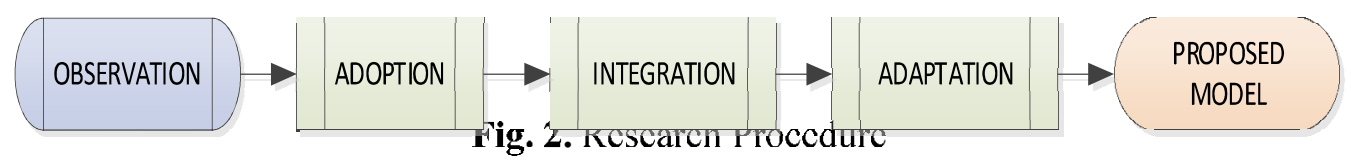

\section{OBSERVATION}

The first step, search for information through the literature study of the previous ITG research model. Then, analyze the relationship between the ITG conceptual mechanism framework model with several other information systems research models whether there is a relationship.

\section{ADOPTION}

In the second step, the authors combined several information systems research models, including the Parasurman Readiness model, the Nielsen Usability model, and the Trust variable, by following the ITG de Haes conceptual mechanism framework model approach.

\section{INTEGRATION}

In the third step, the authors integrate the Readiness model [32], the Usability model [33], and the Trust variable into one part into the ITG framework model. Combining the model still considers the conceptual mechanism framework model ITG de Haes [31]. In this study, model integration consists of three steps of abstract mechanism identification according to the ITG da Haes conceptual model approach, which has three mechanism variables. Three identifications of the ITG conceptual mechanism in the development of integrated models are as follows:

\section{The first integration step}

The first identification is that the author adjusts the first ITG mechanism, namely the relational mechanism. Following the ITG relational mechanism, the relationship between communication practice patterns and synergies between people and information technology. The readiness variable domain in the Parasuraman readiness model describes the relationship between humans as IT users and the IT devices they will use. The Readiness model's four variables explain if hopefulness, breakthrough, discomfort, and insecurity are the starting points of the response between human relationships with IT [32]. The development of the Technology Readiness Index (TRI) model by Parasuraman is a reference for measuring trust in technology [34].

The background of the four readiness technology variables begins with a person's view of technology, namely the hope of addressing technology. In the use of a new technological breakthrough, or it could be that the tendency for the results to appear is that someone feels insecure and uncomfortable with technology. Based on the relational ITG mechanism and the Readiness model, which has a background relationship, it uses the four dimensions of the technology readiness variable domain: 
hopefulness, breakthrough, discomfort, and insecurity as the independent variable domains study.

\section{The second integration step}

The second identification is that the writer adjusts the second ITG mechanism, namely the process mechanism. Following the process mechanism in ITG, it describes IT monitoring, regulation, and evaluation aimed at conformity to rules in IT operations. The Nielsen utility variable domain explains how to monitor, organize, evaluate the quality of information, service quality, and system quality that users use so that user trust in the system appears [33].

The writer adopts Nielsen's five variable usability model into three variable domains of the usability model. Usability is a quality attribute that assesses how easy the user interface is to use or to increase ease of use during the design process. The Usability variable is determined by five components of quality: Learnability, Efficiency, Memory, Error, and Satisfaction. However, to adopt the Usability variable to be only three.

However, each adoption variable has five Usability variables. For example, the variable quality of information has Learnability, Efficiency, Memory, Error, and Satisfaction. Likewise, the system quality variable and service quality variable also have five elements of the Usability variable. They add a new variable to the ITG Trust model as an identification variable for user trust in existing IT. The reason for the need for the trust variable is to determine the extent of the user's trust level after using IT. Finally, through the integration of relational mechanisms and ITG process mechanisms, the next step is to integrate the Readiness domain, the Usability domain, and the variables.

\section{The third integration step}

The final mechanism is a decision-making structure mechanism that determines business decisions and IT management's rights and responsibilities that involve IT in the organization, namely through ITG. Here the ITG variable is a variable for business and management decision-makers.

The three ITG conceptual mechanisms were formed by carrying out the final integration, namely unifying the three conceptual mechanisms: the relational mechanism, the process mechanism, and the decision-making structure mechanism. The ITG Trust Model is formed by having nine variables derived from the Readiness domain variable totaling four variables, the use domain variable counting three variables, the Trust variable as a novelty variable from the ITG model, and finally, the ITG variable as a decision-making structure variable.

\section{PROPOSED MODEL}

The fifth step carried out drawing and naming the variables of the ITG Trust framework model as a new ITG framework model. The model for the ITG Trust framework, as shown in figure 2 


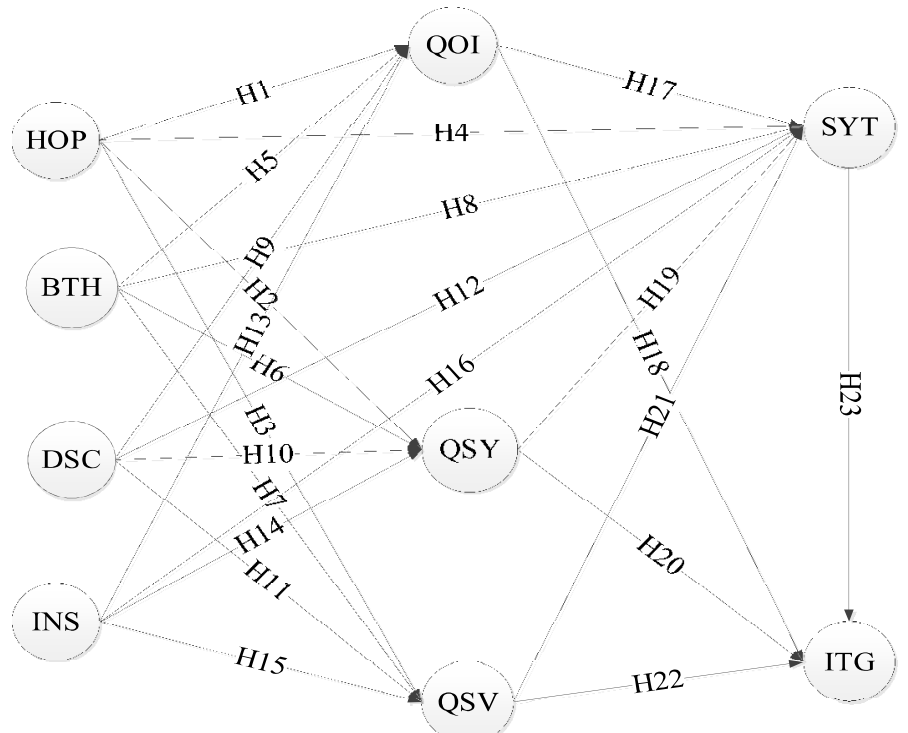

Fig. 2. ITG Trust framework

\section{HYPOTHESIS DEVELOPMENT}

After the ITG Trust framework model is formed, it begins developing a hypothesis based on the study's research object. The research hypothesis can change according to the research object because if the ITG Trust framework can be applied to several research objects other than the research object in the HSI context. In the first step, it explains each variable name in the ITG Trust framework, is shown in table 2

Table 2. Variable and definitions [32], [33], [35]

\begin{tabular}{|c|c|}
\hline Var & Definitions \\
\hline H0P & The quality of believing to the IT \\
\hline BTH & The IT quality is the advanced systems. \\
\hline DSC & The quality of perceiving IT is an unpleasant condition \\
\hline INS & The quality of distrust to IT integration whether can handle harmful potential \\
\hline Q0I & $\begin{array}{l}\text { The quality of IT information depends on the consistency of the user's } \\
\text { expectations }\end{array}$ \\
\hline QSY & The quality of IT System depends on the IT content \\
\hline QSV & The quality of IT Service depends on excellent condition. \\
\hline SYT & The quality of IT satisfaction level depends on trust condition to the IT. \\
\hline ITG & The achievement of the IT governance \\
\hline
\end{tabular}


Table 3. Variable and definitions [32], [33], [35]

\begin{tabular}{|c|c|}
\hline Var & Definitions \\
\hline $\mathrm{H}_{1}$ & $\begin{array}{l}\text { The relational structure mechanism of hopefulness has an influence positive } \\
\text { on information quality. }\end{array}$ \\
\hline $\mathrm{H}_{2}$ & $\begin{array}{l}\text { The relational structure mechanism of hopefulness has an influence positive } \\
\text { on system quality. }\end{array}$ \\
\hline $\mathrm{H}_{3}$ & $\begin{array}{l}\text { The relational structure mechanism of hopefulness has an influence positive } \\
\text { on service quality. }\end{array}$ \\
\hline $\mathrm{H}_{4}$ & $\begin{array}{l}\text { The relational structure mechanism of hopefulness has an influence positive } \\
\text { on the quality of trust in a system }\end{array}$ \\
\hline $\mathrm{H}_{5}$ & $\begin{array}{l}\text { The relational structure mechanism of breakthrough has an influence } \\
\text { positive on information quality. }\end{array}$ \\
\hline $\mathrm{H}_{6}$ & $\begin{array}{l}\text { The relational structure mechanism of breakthrough has an influence } \\
\text { positive on system quality }\end{array}$ \\
\hline $\mathrm{H}_{7}$ & $\begin{array}{l}\text { The relational structure mechanism of breakthrough has an influence } \\
\text { positive on service quality. }\end{array}$ \\
\hline $\mathrm{H}_{8}$ & $\begin{array}{l}\text { The relational structure mechanism of breakthrough has an influence } \\
\text { positive on the quality of trust in a system }\end{array}$ \\
\hline $\mathrm{H}_{9}$ & $\begin{array}{l}\text { The relational structure mechanism of discomfort has an influence positive } \\
\text { on information quality. }\end{array}$ \\
\hline $\mathrm{H}_{10}$ & $\begin{array}{l}\text { The relational structure mechanism of discomfort has an influence positive } \\
\text { on system quality }\end{array}$ \\
\hline $\mathrm{H}_{11}$ & $\begin{array}{l}\text { The relational structure mechanism of discomfort has an influence positive } \\
\text { on service quality. }\end{array}$ \\
\hline $\mathrm{H}_{12}$ & $\begin{array}{l}\text { The relational structure mechanism of discomfort has an influence positive } \\
\text { on the quality of trust in a system }\end{array}$ \\
\hline $\mathrm{H}_{13}$ & $\begin{array}{l}\text { The relational structure mechanism of insecurity has an influence positive on } \\
\text { the information quality. }\end{array}$ \\
\hline $\mathrm{H}_{14}$ & $\begin{array}{l}\text { The relational structure mechanism of insecurity has an influence positive on } \\
\text { system quality }\end{array}$ \\
\hline $\mathrm{H}_{15}$ & $\begin{array}{l}\text { The relational structure mechanism of insecurity has an influence positive on } \\
\text { service quality }\end{array}$ \\
\hline $\mathrm{H}_{16}$ & $\begin{array}{l}\text { The relational structure mechanism of insecurity has an influence positive on } \\
\text { the quality of trust in a system }\end{array}$ \\
\hline $\mathrm{H}_{17}$ & $\begin{array}{l}\text { The process mechanism of quality of information has an influence positive } \\
\text { to trust in a system }\end{array}$ \\
\hline $\mathrm{H}_{18}$ & $\begin{array}{l}\text { The process mechanism of quality of information has an influence positive } \\
\text { on ITG }\end{array}$ \\
\hline $\mathrm{H}_{19}$ & $\begin{array}{l}\text { The process mechanism of the quality of the system has an influence } \\
\text { positive to trust in a system }\end{array}$ \\
\hline $\mathrm{H}_{20}$ & $\begin{array}{l}\text { The process mechanism of the quality of the system has an influence } \\
\text { positive on ITG }\end{array}$ \\
\hline $\mathrm{H}_{21}$ & $\begin{array}{l}\text { The process mechanism of the quality of the IT service has an influence } \\
\text { positive to trust in a system }\end{array}$ \\
\hline $\mathrm{H}_{22}$ & The process mechanism of the quality of the IT service has an influence \\
\hline
\end{tabular}




\begin{tabular}{ll}
\hline Var & \multicolumn{1}{c}{ Definitions } \\
\hline & positive on ITG \\
\hline $\mathrm{H}_{23}$ & $\begin{array}{l}\text { The relational structure mechanism of the satisfaction in trust on a system } \\
\text { has an influence positive on ITG }\end{array}$ \\
\hline
\end{tabular}

\section{CONCLUSION}

ITG is an essential part of corporate governance to function, monitor information technology capability decisions, and manage the risk of technology-related losses. The goal of ITG is IT decisions that impact business value and foster the trust of stakeholders. The ITG procedure controls IT that may have an influence- positive or negative - on business results. The importance of ITG is evident based on more attention by scholars and practitioners. For the research results of the ITG Trust framework in the context of the research object at the HSI, its hope to be a stepping stone for further ITG research at the HSI level apart from the ITG research context HEI level. For other research recommendations, there will be a study of the effectiveness of ITG for the HSI level by assessing the conceptual mechanism of ITG at the management level and the CEO level. Finally, with the existence of ITG at the HSI level, it hopes that the ITG Trust framework will be able to explain the contributing factors of ITG through its impact, validating, and testing the framework. The results of further validation will contribute to knowledge in ITG at HSI.

\section{ACKNOWLEDGMENTS}

The authors are grateful to the Asia e University for supporting this paper. This paper is part of my thesis Ph.D. ICT in Asia e University. We also thank state and private HSI principals in Jakarta, Bekasi, and Tangerang for the invaluable advice.

\section{REFERENCES}

[1] O. Turel, P. Liu, and C. Bart, "Board-Level Information Technology Governance Effects on Organizational Performance: The Roles of Strategic Alignment and Authoritarian Governance Style," Inf. Syst. Manag., vol. 34, no. 2, pp. 117-136, 2017, DOI: $10.1080 / 10580530.2017 .1288523$.

[2] R. Setyadi, A. Fattah, and B. Waseso, "Trust Effect on Business-IT Governance Alignment in Society Culture (A Case Study in Indonesia)," 2019 7th Int. Conf. Cyber IT Serv. Manag. CITSM 2019, no. January 2020, pp. 2-7, 2019, DOI: 10.1109/CITSM47753.2019.8965411.

[3] H. C. Chae, C. E. Koh, and K. O. Park, "Information technology capability and firm performance: Role of industry," Inf. Manag., vol. 55, no. 5, pp. 525-546, 2018, DOI: 10.1016/j.im.2017.10.001.

[4] R. Tripathi, "From information to interaction': Website and social media usage and trends in top Indian higher education institutions," Int. J. Bus. Inf. Syst., vol. 29, no. 2, pp. 139-154, 2018, DOI: 10.1504/IJBIS.2018.094690.

[5] Y. Limani, E. Hajrizi, L. Stapleton, and M. Retkoceri, "Digital transformation readiness http://ijstm.inarah.co.id 
in higher education institutions (HEI): the case of kosovo," IFAC-PapersOnLine, vol. 52, no. 25, pp. 52-57, 2019, DOI: 10.1016/j.ifacol.2019.12.445.

[6] Anwar Fattah, Hoga Saragih, and Resad Setyadi, "Determinants Effectiveness of Information Technology Governance and IT Performance in Higher Education Institution (HEI): A Conceptual Framework," Int. J. Sci. Technol. Manag., vol. 2, no. 1, pp. 36-47, 2021, DOI: 10.46729/ijstm.v2i1.135.

[7] S. Harguem, "A conceptual framework on IT governance impact on organizational performance: A dynamic capability perspective," Acad. J. Interdiscip. Stud., vol. 10, no. 1, pp. 136-151, 2021, DOI: 10.36941/ajis-2021-0012.

[8] D. Haouam, "IT governance impact on financial reporting quality using COBIT framework," Glob. J. Comput. Sci. Theory Res., vol. 10, no. 1, pp. 1-10, 2020, DOI: 10.18844/gjcs.v10i1.4143.

[9] M. Khouja, I. B. Rodriguez, Y. Ben Halima, and S. Moalla, "IT governance in higher education institutions: A systematic literature review," Int. J. Hum. Cap. Inf. Technol. Prof., vol. 9, no. 2, pp. 52-67, 2018, DOI: 10.4018/IJHCITP.2018040104.

[10] B. A. Ajayi and H. Hussin, "IT governance from practitioners' perspective: Sharing the experience of a Malaysian university," J. Theor. Appl. Inf. Technol., vol. 88, no. 2, pp. 219-230, 2016.

[11] S. A. Busru and G. Shanmugasundaram, "Effects of innovation investment on profitability and moderating role of corporate governance: empirical study of Indian listed firms," Indian J. Corp. Gov., vol. 10, no. 2, pp. 97-117, 2017, DOI: 10.1177/0974686217730938.

[12] H. Sofyani, H. A. Riyadh, and H. Fahlevi, "Improving service quality, accountability and transparency of local government: The intervening role of information technology governance," Cogent Bus. Manag., vol. 7, no. 1, 2020, DOI: 10.1080/23311975.2020.1735690.

[13] M. O'Connell and A. M. Ward, Corporate Governance, Measurement of. 2020.

[14] A. Fattah and R. Setyadi, “... Effectiveness Information Technology Governance in Higher Education Institution (HEI) Using Partial Least Squares Structural Equation (PLS-SEM) Modelling ...," ... Sci. Inf. Technol. ..., 2019, [Online]. Available: https://www.researchgate.net/profile/Anwar_Fattah/publication/335541608_Determina nts_Effectiveness_Information_Technology_Governance_in_Higher_Education_Institu tion_HEI_using_partial_least_squares_structural_equation_Modeling_approach_PLSSEM/links/5df195.

[15] L. Rusu and G. M. Jonathan, IT Alignment in Public Organizations: A Systematic Literature Review. 2017.

[16] T. Kude, M. Lazic, A. Heinzl, and A. Neff, "Achieving IT-based synergies through regulation-oriented and consensus-oriented IT governance capabilities," Inf. Syst. J., vol. 28, no. 5, pp. 765-795, 2018, DOI: 10.1111/isj.12159.

[17] Y. Tjong, S. Adi, H. Prabowo, and R. Kosala, "Benefits to implementing IT governance in higher education: (Systematic literature review)," Proc. 2017 Int. Conf. Inf. Manag. Technol. ICIMTech 2017, vol. 2018-Janua, no. November, pp. 35-38, 2018, DOI: 10.1109/ICIMTech.2017.8273507.

[18] R. M. Tawafak, A. Romli, S. I. Malik, and M. Shakir, "IT Governance Impact on Academic Performance Development," Int. J. Emerg. Technol. Learn., vol. 15, no. 18, 
pp. 73-85, 2020, DOI: 10.3991/ijet.v15i18.15367.

[19] F. M. Alkhaldi, S. M. Hammami, and M. A. Uddin, "Understating value characteristics toward a robust IT governance application in private organizations using COBIT framework," Int. J. Eng. Bus. Manag., vol. 9, pp. 1-8, 2017, DOI: $10.1177 / 1847979017703779$.

[20] A. O. Tonelli, P. H. de Souza Bermejo, P. Aparecida dos Santos, L. Zuppo, and A. L. Zambalde, "It governance in the public sector: a conceptual model," Inf. Syst. Front., vol. 19, no. 3, pp. 593-610, 2017, doi: 10.1007/s10796-015-9614-x.

[21] S. de Haes and W. van Grembergen, "An Exploratory Study into IT Governance Implementations and its Impact on Business/IT Alignment," Inf. Syst. Manag., vol. 26, no. 2, pp. 123-137, 2009, DOI: 10.1080/10580530902794786.

[22] P. Weill and R. Woodham, "Don't Just Lead, Govern: Implementing Effective IT Governance," SSRN Electron. J., 2005, DOI: 10.2139/ssrn.317319.

[23] G. S. Kearns and R. Sabherwal, "Strategic alignment between business and information technology: A knowledge-based view of behaviors, outcome, and consequences," $J$. Manag. Inf. Syst., vol. 23, no. 3, pp. 129-162, 2006, DOI: 10.2753/MIS07421222230306.

[24] P. Sirisomboonsuk, V. C. Gu, R. Q. Cao, and J. R. Burns, "Relationships between project governance and information technology governance and their impact on project performance," Int. J. Proj. Manag., vol. 36, no. 2, pp. 287-300, 2018, doi: 10.1016/j.ijproman.2017.10.003.

[25] S. Turedi and H. Zhu, "How to generate more value from IT: The interplay of it investment, decision making structure, and senior management involvement in IT governance," Commun. Assoc. Inf. Syst., vol. 44, no. 1, pp. 511-536, 2019, doi: 10.17705/1CAIS.04426.

[26] S. Ping-Ju Wu, D. W. Straub, and T.-P. Liang, "How information technology governance mechanisms and strategic alignment influence organizational performance," MIS Q., vol. 39, no. 2, pp. 497-518, 2015.

[27] P. Willson and C. Pollard, "Exploring IT governance in theory and practice in a large multi-national organisation in Australia," Inf. Syst. Manag., vol. 26, no. 2, pp. 98-109, 2009, DOI: 10.1080/10580530902794760.

[28] G. C. Wiedenhoft, E. M. Luciano, and O. A. Magnagnagno, "Information Technology Governance in Public Organizations: Identifying Mechanisms That Meet Its Goals While Respecting Principles," J. Inf. Syst. Technol. Manag., vol. 14, no. 1, pp. 69-87, 2017, DOI: 10.4301/s1807-17752017000100004.

[29] P. Stachtchenko, "Taking Governance Forward," ISACA J., vol. 6, pp. 1-2, 2008, [Online]. Available: http://www.isaca.org/Journal/Past-Issues/2008/Volume6/Pages/Taking-Governance-Forward1.aspx.

[30] I. Rychkova and J. Zdravkovic, "Towards Decentralized IT Governance in the Public Sector: A Capability-oriented Approach,” pp. 107-132, 2017, DOI: 10.1007/978-3-31958978-7_5.

[31] S. De Haes and W. Van Grembergen, "IT governance and its mechanisms," Proc. Annu. Hawaii Int. Conf. Syst. Sci., vol. 8, p. 193, 2004, DOI: 10.1109/HICSS.2006.322.

[32] A. Parasuraman, "Technology Readiness Index (TRI): A Multipleitem Scale To Measure Readiness To Embrace New Technologies," J. Serv. Res., vol. 2:307, no. http://ijstm.inarah.co.id 
May, 2000.

[33] J. Nielsen, "Usability 101: Introduction to Usability," 2012. https://www.nngroup.com/articles/usability-101-introduction-to-usability/.

[34] A. Parasuraman and C. L. Colby, “An Updated and Streamlined Technology Readiness Index: TRI 2.0,” J. Serv. Res., vol. 18, no. 1, pp. 59-74, 2015, doi: $10.1177 / 1094670514539730$.

[35] A. Subiyakto and A. R. Ahlan, "Implementation of Input-Process-Output Model for Measuring Information System Project Success," TELKOMNIKA Indones. J. Electr. Eng., vol. 12, no. 7, 2014, DOI: 10.11591/telkomnika.v12i7.5699. 